\title{
Integration of Apoptosis and Metabolism
}

\author{
C.H. Yi, H. VAKifahmetoglu-NoRberg, and J. Yuan \\ Department of Cell Biology, Harvard Medical School, Boston, Massachusetts 02115 \\ Correspondence:jyuan@hms.harvard.edu
}

\begin{abstract}
Apoptotic resistance is a hallmark of human cancers. Recent advances have contributed to our understanding of the molecular mechanisms that intimately integrate cell metabolism and apoptosis. Coordinated activation of the proapoptotic Bcl-2 family and the caspase family during apoptosis often leads to permeabilization of the mitochondrial outer membrane and release of multiple enzymes that normally function in regulating energy production and metabolism. The roles of these metabolic enzymes in promoting caspase activation demonstrate a primordial need to couple apoptotic cell death and metabolic catastrophe during cellular destruction. The Bcl-2 family also directly interacts with the multiple metabolic regulators to protect or promote mitochondrial damage during apoptosis. However, the integration of metabolism and apoptosis is not simply limited to the maintenance of mitochondrial integrity. A recent study demonstrates that the NatA complex, a protein $N$ - $\alpha$-acetyltransferase complex, is required for DNA damage-mediated apoptosis and suggests that regulation of protein acetylation might provide an important mechanism for regulating apoptotic sensitivity. Since acetyl-CoA (coenzyme A) is a key cofactor for the NatA complex, protein acetylation is subject to the availability of acetyl-CoA and, thus, under metabolic regulation. The revelation that protein $N$ - $\alpha$-acetylation is regulated by Bcl-xL, a major antiapoptotic mitochondrial protein, demonstrates a mechanism by which metabolism can regulate the activation of multiple key apoptotic factors simultaneously.
\end{abstract}

More than a half century ago, Otto Warburg discovered that cancer cells prefer glycolysis, a rather inefficient metabolic pathway for reducing glucose into energy (Warburg 1956). This peculiar preference of tumor cells has since been recognized as a metabolic hallmark of cancers. Since evading apoptosis is critical for cancer cells to achieve uncontrolled growth and proliferation, the metabolic features of cancers must play an important role in regulating the apoptosis machinery. Thus, a molecular understanding of the link between metabolism and apoptotic sensitivity is warranted.

Apoptosis is a highly regulated form of cell death that functions to maintain tissue homeostasis by eliminating unnecessary or damaged cells. In Caenorhabditis elegans, developmental apoptosis is controlled by an elegant and linear genetic program. In mammals, however, the core apoptotic program has been dramatically expanded, resulting in an intricate suite of regulatory pathways that influence apoptotic sensitivity. Although biochemical approaches have uncovered many factors that regulate apoptotic cell death, it is clear that elimination of many downstream proapoptotic effecters are not sufficient for evading the fate of cell death (Marsden et al. 2002). The complexity of the mammalian apoptotic pathways suggests that it is the summation of multiple intracellular signaling events, rather than a simple linear pathway, that determines a cell's final fate to live or die.

Recent studies indicate that the apoptotic network is incorporated into multiple cell physiological processes, including cell metabolism (Yuan 2006). Our understanding of how these homeostatic processes influence apoptotic sensitivity at the molecular level is now emerging. In this review, we describe recent findings that reveal an intimate integration of cellular metabolism and apoptosis. New insights into this problem will reveal powerful mechanisms whereby cancer cells evade cell death and identify new targets for cancer therapy.

\section{PART I. THE CORE APOPTOTIC MACHINERY}

\section{Caspases, A Family of Cysteine Proteases that Mediate Apoptosis}

The first key insights into the molecular mechanisms regulating apoptotic cell death came from genetic studies in the nematode C. elegans (Yuan et al. 1993). These genetic studies revealed that the apoptotic pathway can be activated in all cells and that the canonical apoptotic machinery is highly conserved in all metazoans from invertebrates to vertebrates (Miura et al. 1993; Degterev et al. 2003). The apoptotic machinery is operated by the coordinated regulation of multiple signal transducers, receptors, enzymes, and gene-regulating proteins. Among the master regulators of programmed cell death, the family of cysteine proteases known as caspases is critical for mediating the signal transduction and execution of apoptosis. While CED-3 is the solitary caspase required for programmed cell death in C. elegans, numerous caspases are required for apoptosis in more complex organisms, such as Drosophila (seven caspases) and mammals (10 caspases in mouse and 11 caspases in human; Degterev et al. 2003). Such extensive expansion of the caspase family during evolution warrants multiple modes of regulation to keep inappropriate caspase activation at bay and is described below. 
Depending on the mode of their activation, the members of the caspase family are classified as the upstream "initiator" caspases (in fly, Dredd, Dronc, Strica; in mammals, caspase-1, -2, -4, -5, -8, -9, -10, -11, -12), which respond to prodeath signals, or the downstream "executioner" caspases (in fly, Drice, Dcp-1, Decay, Damm; in mammals, caspase-3, -6, -7, -14) that are activated upon their proteolytic cleavage by the initiator caspases. The initiator caspases contain a long amino-terminal prodomain, which allows the formation of protein complexes that regulate their activation and inhibition. Caspases are synthesized as inactive zymogens, known as procaspases, that require allosteric conformational changes and/or specific cleavage after a select aspartate residue to become activated. The initial processing of the inactive caspase separates the large and small subunits, followed by the removal of the amino-terminal domain to form the catalytically active protease (Degterev et al. 2003). Consequently, caspase activation leads to a cascade of extensive proteolytic events at the proteome level that ultimately results in apoptotic cell death (Van Damme et al. 2005; Dix et al. 2008; Mahrus et al. 2008; Simon et al. 2009).

\section{Caspase-Activating Complexes}

Through homotypic interactions with the prodomains of caspases, adaptor proteins facilitate the assembly of large multimeric complexes as caspase activation platforms. The recruitment of specific initiator caspases is determined by their long prodomain via a caspaserecruitment domain (CARD; in C. elegans, CED-3; in Drosophila melanogaster, Dronc; in mammals, caspase-1, $-2,-4,-5,-9,-11,-12$ ) or death-effector domain (DED; in D. melanogaster, Dredd; in mammals, caspase-8, -10; Degterev et al. 2003). In response to specific developmental cues, the adaptor protein CED-4, which is composed of an amino-terminal CARD and a nucleotide-binding domain (NBD, also known as nucleotide-oligomerization domain, NOD), oligomerizes to promote the activation of CED-3 (Yang et al. 1998). Drosophila Apaf-1 (also called Dark, Hac-1, or Dapaf-1), a CED-4-like molecule, is responsible for the activation of the major fly initiator caspase, Dronc, in response to cellular stresses such as DNA damage (Kanuka et al. 1999; Rodriguez et al. 1999; Zhou et al. 1999). While a single adaptor protein, CED-4, is required for the activation of CED-3 in C. elegans, multiple adaptor proteins are required for caspase activation in mammals by promoting the formation of unique protein complexes under different conditions.

In mammals, four specific caspase-activating complexes have been characterized (Festjens et al. 2006). These complexes include the apoptosome, which mediates the activation of caspase- 9 via interaction with the adaptor APAF-1 (apoptotic protease-activating factor-1) in the presence of cytochrome $c$, a component of the mitochrondrial electron transport system; the death-inducing signaling complex (DISC), which mediates the activation of caspase- 8 via interaction with the adaptor FADD; the inflammasomes, which mediate the activation of caspase- 1 and caspase- 5 via interaction with the adaptors ASC (apoptosis-associated speck-like protein containing a CARD) or the family of NLRs (nucleotide-binding and oligomerization domain-like receptors); and the PIDDosome, which mediates the activation of caspase- 2 via interaction with the adaptors RAIDD (RIP [receptorinteracting protein]-associated ICH-1/CED-3 homologous protein with a death domain; also called CRADD; Duan and Dixit 1997) and PIDD (p53-induced protein with a death domain; Tinel and Tschopp 2004). Intriguingly, two of these activating complexes are intimately connected to cell metabolism. The apoptosome is formed in response to cytochrome $c$ release resulting from the loss of mitochondrial integrity, and the PIDDosome responds to DNA damage and metabolic stress (Tinel and Tschopp 2004; Nutt et al. 2005, 2009).

\section{A Mitochondrial Role in Caspase Activation}

The Apoptosome in Mammals. The discovery that cytochrome $c$, a mitochrondrial intermembrane space protein, participates in the apoptotic program in mammalian cells provided the first evidence for a mitochondrial function in apoptosis (Liu et al. 1996). This observation suggests that cells may have a coordinated program to rupture mitochondria during apoptosis. Cytochrome $c$ is essential for the electron transport chain and loss of the gene encoding cytochrome $c$ leads to embryonic lethality. However, cytochrome $c$-deficient cells show increased resistance in response to proapoptotic stimuli, such as UV radiation, serum withdrawal, and staurosporine (Li et al. 2000). Specific mutations in cytochrome $c$ that preserve the electron transport function but not oligomerization to Apaf-1 have been identified (K72A), separating the apoptotic and metabolic function of cytochrome $c$ (Yu et al. 2001; Hao et al. 2005). Furthermore, in vitro studies demonstrate that, once in the cytosol, cytochrome $c$ assembles together with Apaf-1 to form a caspase-9-activating complex in the presence of dATP/ ATP that promotes caspase-3 activation (Li et al. 1997; Zou et al. 1997). Intramolecular interaction of the amino-terminal CARD and carboxy-terminal WD40 repeat region results in autoinhibition of Apaf-1 (Srinivasula et al. 2001). However, cytochrome $c$ overrides the autoinhibition of Apaf-1 by binding to the WD40 repeat region, releasing the CARD for apoptosome assembly (Acehan et al. 2002). Presumably, Apaf-1 bound to ATP/dATP further supports an active conformation, where the amino-terminal CARD is free to bind to caspase-9 (Riedl et al. 2005). The resulting conformational change facilitates the formation of the heptameric structure of the apoptosome (Acehan et al. 2002). Taken together, these observations show that the loss of mitochondrial integrity and subsequent cytochrome $c$ release as well as apoptosome formation promotes the caspase cascade in mammalian cells. The intriguing participation of cytochrome $c$, a key metabolic enzyme, as a signal amplifier during apoptosis may demonstrate a primordial need for metabolic catastrophe during cellular destruction. 


\section{The Bcl-2 Family}

Studies in C. elegans indicate that the proteolytic caspase cascade is under tight regulation by CED-9 and EGL-1. In mammalian cells, the orthologs of CED-9 and EGL-1, termed the Bcl-2 (B-cell lymphoma 2) family of proteins, include both anti- and proapoptotic members and are the main regulators of the mitochondrial outer membrane permeabilization (MOMP). Based on the presence of four conserved Bcl-2 homology (BH) domains, Bcl-2 family members are further categorized into three subgroups, namely, prosurvival, multidomain proapoptotic, and $\mathrm{BH} 3$-only $\mathrm{Bcl}-2$ proteins.

The prosurvival Bcl-2 members (in C. elegans, CED-9; in mammals, Bcl-2, Bcl-xL [Bcl-extra large], Mcl-1, Mcl-A1, Bcl-w) serve as the major inhibitors of apoptosis and contain four $\mathrm{BH}$ domains (BH1-4). However, in contrast to $\mathrm{CED}-9, \mathrm{Bcl}-2 / \mathrm{Bcl}-\mathrm{xL}$ do not directly bind and inhibit Apaf-1, suggesting that the evasion of apoptosis mediated by Bcl-2/Bcl-xL in mammals is distinct from that of $C$. elegans (Moriishi et al. 1999; Conus et al. 2000; Hausmann et al. 2000). In Drosophila, the protein Buffy (dBorg-2) most likely functions as an anti-apoptotic Bcl-2-like protein, despite the lack of an obvious BH4 domain (Quinn et al. 2000).

The multidomain proapoptotic proteins, Bax (Bcl-2 associated $\mathrm{X}$ protein) and Bak (Bcl-2 homologous antagonist/killer), contain three $\mathrm{BH}$ domains (BH1 - 3). Oligomerization of Bax and Bak during apoptosis plays an important role in MOMP during apoptosis. In Drosophila, Drob-1/Debcl/dBorg-1/dBok is a proapoptotic Bcl-2 family member that functions upstream of caspase activation (Brachmann et al. 2000; Colussi et al. 2000; Igaki et al. 2000; Zhang et al. 2000; Galindo et al. 2009). The exact mechanism, however, by which Drob-1/Debcl/dBorg-1/dBok regulates caspase activation remains to be determined, as mitochondria do not seem to have a pivotal role in apoptotic cell death in Drosophila.

The BH3-only proteins (in C. elegans, EGL-1; in mammals, Bim, Bad, Bid, Bik, Bmf, Puma, Noxa, and Hrk) function as early sensors to distinct death cues and, upon stimulation, activated $\mathrm{BH} 3$-only members mediate a cellular stress signal through protein-protein interactions with other Bcl-2 family proteins. Notably, any possible Drosophila orthologs of the BH3-only proteins have not yet been identified, suggesting that the cell death pathway may be regulated in a different manner between flies and mammals.

The members of the Bcl-2 family of proteins are either localized or targeted to the outer mitochondrial membrane to promote or to prevent MOMP, which is discussed below.

Prosurvival Bcl-2 Members. Bcl-2 and Bcl-xL proteins play pivotal roles in mediating apoptotic inhibition. $\mathrm{Bcl}-2$ expression has been associated with suppression in cytochrome $c$ release from mitochondria induced by various death signals (Kluck et al. 1997; Yang et al. 1997). Prosurvival Bcl-2 family members play important roles in negatively regulating developmental cell death in mice (McDonnell et al. 1989) and C. elegans (Vaux et al. 1992). Concordantly, thymocytes deficient in Bcl-2 display massive apoptotic cell death in response to a variety of apoptotic signals (Nakayama et al. 1993; Veis et al. 1993; Kamada et al. 1995). These findings provide strong evidence that $\mathrm{Bcl}-2$ is an antiapoptotic molecule. In addition, both $\mathrm{Bcl}-2$ and $\mathrm{Bcl}-\mathrm{xL}$ are required for maturation of lymphoid precursor cells. However, only Bcl-xL is required for early murine development, suggesting that Bcl-2 and Bcl-xL may have nonoverlapping functions in vivo (Motoyama et al. 1995). These studies establish that apoptosis inhibition by $\mathrm{Bcl}-2$ and $\mathrm{Bcl}-\mathrm{xL}$ is important for normal mammalian development.

In addition to early developmental regulation, $\mathrm{Bcl}-2$ and Bcl-xL contribute to pathological situations, such as cancer development as well as tumor maintenance. In fact, Bcl-2 was initially identified as a proto-oncogene implicated in human follicular lymphomas carrying the $\mathrm{t}(14: 18)$ chromosomal translocation (Tsujimoto et al. 1985a,b,c). Expression of Bcl-2 as well as Bcl-xL also protects thymocytes against multiple pathological insults, such as radiation, growth factor withdrawal, and heat stress (Tsujimoto 1989; Sentman et al. 1991; Boise et al. 1993). Bcl-2 has been shown to promote proliferation of B-cell precursor cells in cooperation with the oncogene, $c$-myc (Strasser et al. 1990). Consistently, Bcl-2 dramatically enhances tumor formation in mice expressing $c$-myc under the control of the Igh enhancer, Em. These observations demonstrate the oncogenic activity of $\mathrm{Bcl}-2$ in regulating apoptotic sensitivity and a critical role of apoptotic resistance in tumorigenesis.

Multidomain Proapoptotic Bcl-2 Members. Bax and Bak, the two major proapoptotic multidomain Bcl-2 family members, function by interacting and antagonizing the antiapoptotic members of the family such as Bcl-2 and Bcl-xL (Oltvai et al. 1993; Farrow et al. 1995). Overexpression of either of Bax or Bak is sufficient to accelerate apoptotic cell death, suggesting that increased protein levels of these proteins could overcome the inhibitory effect of Bcl-2/Bcl-xL. This finding led to the proposal that the ratio of proteins levels of $\mathrm{Bcl}-2$ (or Bcl-xL) to Bax (or Bak) functions as a "rheostat" to determine the threshold for a cell to live or die in response to apoptotic stimuli (Korsmeyer et al. 1993). Although the control of apoptotic sensitivity in mammalian cells is now known to be much more complicated than this simple "rheostat," the heterodimerization of Bcl-2 and Bax is important for controlling the ability of Bax to induce cell death (Yang et al. 1995).

Bax and Bak normally exist as inactive monomers in cells and are activated by $\mathrm{BH} 3$-only proteins, such as Bid. Upon stimulation by an apoptotic signal, Bak, normally bound to the outer mitochondrial membrane, undergoes a conformational change and oligomerizes in the membrane, leading to pore formation in the lipid bilayer through which mitochondrial proteins can be 
released into the cytosol. Unlike Bak, Bax, mainly found in the cytosol under normal conditions, translocates to the surface of the mitochondria during apoptosis (Wolter et al. 1997). Once at the mitochondria, Bax form clusters in the outer mitochondrial membrane and facilitates pore formation through which cytochrome $c$ is released (Jurgensmeier et al. 1998; Saito et al. 2000; Nechushtan et al. 2001). Cells lacking both Bax and Bak show defects in cytochrome $c$ release in response to multiple prodeath signals (Wei et al. 2001), and mice deficient in Bax and Bak present a marked cell death phenotype (Lindsten et al. 2000). Thus, because the oligomerization of Bax and Bak appears to be a prerequisite for mitochondrial outer membrane permeabilization, these two proteins are considered to be the "gatekeepers" of mitochondrial dysfunction during apoptosis.

Although the antiapoptotic function of Bcl-2/Bcl-xL has been widely accepted as a direct consequence of inhibiting Bax/Bak-dependent mitochondrial dysfunction, there is evidence that $\mathrm{Bcl}-2 / \mathrm{Bcl}-\mathrm{xL}$ may have additional antiapoptosis activity independent of Bax/Bak. As discovered by Hardwick and colleagues, certain Bcl-xL mutants that are unable to heterodimerize with Bax or Bak nevertheless still retain substantial anti-apoptotic activity $(70 \%-80 \%)$ against viral infection and growth factor withdrawal (Cheng et al. 1996), suggesting that the inhibitory effect of Bcl-xL on apoptosis is not solely mediated by antagonizing Bax or Bak. Consistently, Bcl-2 expression provides much more profound protection against apoptotic stimuli than the loss of Apaf-1 or caspase-9, the major downstream mediator of mitochondrial damage in apoptosis (Marsden et al. 2002). These results suggest the possibility that either Bcl-2 or Bcl-xL may exert apoptotic resistance through additional pathway(s) beyond interacting with Bax/Bak, or oligomerization of Bax and Bak may not be the only event leading to sensitization of mammalian cells to apoptosis. Since Bcl-2/Bcl-xL overexpression is the most effective cellular barrier against apoptosis (Marsden et al. 2002), it is critical to uncover additional pathways regulated by $\mathrm{Bcl}-2 / \mathrm{Bcl}-\mathrm{xL}$ to obtain a full mechanistic understanding of how apoptotic resistance promotes cancer development.

BH3-Only Proteins. BH3-only proteins function upstream of mitochondrial permeabilization and are required for apoptosis induced by cytotoxic stimuli. Once activated, BH3-only proteins insert their BH3 domain, an amphipathic $\alpha$-helix, into a hydrophobic pocket of the antiapoptotic Bcl-2 family members (Petros et al. 2000; Liu et al. 2003; Yan et al. 2004). The heterodimerization between these proteins sets the threshold for cells to undergo apoptosis. Although this is most likely a general mode of action for BH3-only proteins, including EGL-1 in C. elegans, these proteins were found to have different affinities for each prosurvival Bcl-2 protein (Chen et al. 2005). For example, whereas Bim and Puma can tightly bind to all antiapoptotic Bcl-2 members, Bad and Noxa are more restricted in their binding affinities. Thus, in response to apoptotic signals, $\mathrm{BH} 3$-only proteins unleash the apoptotic cascade by inactivating the protective function of the prosurvival members of the Bcl-2 family and by activating the Bax/Bax-like proapoptotic family members. In fact, apoptosis induced by the expression of constitutively active $\mathrm{BH} 3$-only proteins fails to occur in the absence of Bax/Bak (Cheng et al. 2001; Zong et al. 2001).

Two alternative models have been proposed to explain the activation mechanism of Bax and Bak. The antiapoptotic protein neutralization model, which is considered as a modern interpretation of the rheostat model, is based on the hypothesis that the proapoptotic protein function overcomes inhibition by the antiapoptotic proteins. This model suggests that antiapoptotic proteins constitutively inhibit the function of Bax and Bak to ensure mitochondrial integrity and survival. MOMP is indirectly promoted by Bax and/or Bak oligomerization when all antiapoptotic proteins are functionally neutralized by activated (either transcriptional or posttranslational) BH3-only proteins. Accordingly, this mechanism is referred to as the "indirect activation" model (Chen et al. 2005; Willis et al. 2005; Uren et al. 2007; Willis et al. 2007). The observation that mice deficient in both Bim and Bid (Willis et al. 2007) or Bim and Puma (Erlacher et al. 2006) develop normally and cells derived from these mice remain sensitive to death signals supports the indirect activation model.

The observation that $\mathrm{BH} 3$ peptides from Bid and Bim induced Bak-dependent cytochrome $c$ release from isolated mitochondria led to the proposal of an alternative "direct activation model" (Letai et al. 2002). Consistently, a recent study using Förster resonance energy transfer to directly assess protein-protein and proteinmembrane interactions found that tBid (truncated Bid) is sufficient to induce oligomerization of Bax in liposomes and membrane permeabilization (Lovell et al. 2008), suggesting that selected $\mathrm{BH} 3$-only proteins may directly activate proapoptotic Bcl-2 family members. The direct activation model refers to a direct Bax/Bak conformation change and/or translocation to mitochondria by the BH3-only proteins through a transient protein-protein interaction. In this model, BH3-only proteins are categorized into two classes: "the activators," including activated tBid and Bim, which directly bind and activate Bax/Bak, and "the sensitizers," including the remaining $\mathrm{BH} 3$-only proteins, which release antiapoptotic Bcl-2 members to allow for Bax/Bak activation (Kuwana et al. 2005; Certo et al. 2006; Oh et al. 2006; Walensky et al. 2006). This model predicts that the interaction between the released direct activators with Bax or Bak is the key event necessary to engage MOMP, whereas preventing this interaction by the antiapoptotic $\mathrm{Bcl}-2$ proteins is crucial for mitochondrial integrity and cellular survival.

It is possible to unify the direct and indirect activation models such that the $\mathrm{BH} 3$-only proteins at least in part contribute to induction of apoptotic cell death by facilitating both Bax- and Bak-dependent mitochondrial damage and inhibition of prosurvival $\mathrm{Bcl}-2$ members for regulating apoptotic sensitivity. 


\section{PART II. REGULATION OF METABOLISM BY APOPTOTIC FACTORS}

Apoptotic inhibition and maintenance of the cellular metabolic status are essential for cell survival. Therefore, integration of the signaling networks that control apoptosis and cell metabolism would provide a parsimonious system to coordinate these two cellular functions. Indeed, a number of apoptotic factors that are specifically localized to mitochondria are shown to directly regulate mitochondrial physiology and metabolism. These proteins include both the anti- and proapoptotic Bcl-2 family members and proteins localized to the inner membrane space of mitochondria that are released upon apoptotic insult.

\section{Bcl-2 Family and Cell Metabolism}

In vertebrate cells, survival and death signals converge on the Bcl-2 family members that culminate in specific alterations in mitochondrial integrity and function as described above. Under apoptotic conditions, the loss of mitochondrial inner membrane potential leads to mitochondrial collapse, and apoptotic cell death results from the release of mitochondrial proapoptotic factors facilitating the cascade of caspase activity, which coincide with mitochondrial dysfunction and bioenergetic crisis. Under basal conditions, however, multiple members of the Bcl-2 family direct alternative homeostatic functions to maintain mitochondrial physiology.

Bcl-2 family members maintain mitochondrial respiration by controlling mitochondrial outer and inner membrane integrity. Multiple $\mathrm{Bcl}-2$ proteins interact with components of the mitochondrial permeability transition (PT) pore, which is involved in maintenance of mitochondrial volume homeostasis. This multiprotein complex is proposed to connect the inner and outer mitochondrial membranes to mediate communication between the metabolic processes occurring within the mitochondrial matrix, intermembrane space, and the cytoplasm (Zoratti and Szabo 1995). Components of the PT pore include the voltage-dependent anion channel (VDAC), the adenine nucleotide translocator (ANT), and cyclophilin $\mathrm{D}$, which are located in the outer membrane, inner membrane, and mitochondrial matrix, respectively (Green and Kroemer 2004).

Both structural and biochemical studies indicate that recombinant $\mathrm{Bcl}-\mathrm{xL}$ can form a pore-forming complex in liposomes (Muchmore et al. 1996; Minn et al. 1997). This pore complex was suggested to function as a $\mathrm{pH}$-sensitive cation-selective channel, implying Bcl-xL function in regulating mitochondrial permeability (Minn et al. 1997). Moreover, Bcl-xL expression was shown to prevent mitochondrial swelling induced by multiple apoptotic stimuli and to facilitate mitochondrial ATP/ADP exchange to promote cell survival. Whether this is a consequence of the pore-forming property of Bcl-xL is still unclear (Vander Heiden et al. 1997, 1999). In isolated mitochondria from cells deprived of growth factor, recombinant $\mathrm{Bcl}-\mathrm{xL}$ was found to promote the open configuration of
VDAC to facilitate metabolite exchange, including ADP (Vander Heiden et al. 2001). Thus, it is possible that Bcl-xL may alter mitochondrial permeability and volume homeostasis by influencing the open/closed configuration of VDAC. Furthermore, Bcl-xL expression may result in more profound changes in cellular metabolism as ectopic expression of $\mathrm{Bcl}-\mathrm{xL}$ rescues certain yeast mutants that are unable to grow on a nonfermentable carbon source (Vander Heiden et al. 2002). This suggests that $\mathrm{Bcl}-\mathrm{xL}$ might exert a homeostatic function in promoting oxidative phosphorylation, but the exact metabolic changes resulting from $\mathrm{Bcl}-\mathrm{xL}$ expression remains to be determined.

In contrast to $\mathrm{Bcl}-\mathrm{xL}$, tBid reduces the mitochondrial metabolite exchange as the addition of recombinant tBid to reconstituted liposomes with VDAC promotes the close configuration of VDAC (Rostovtseva et al. 2004). Since direct interaction between tBid and VDAC has not been observed (Shimizu and Tsujimoto 2000), tBid most likely exerts an indirect influence on VDAC function in cells. These studies suggest that the Bcl-2 family of proteins might either support mitochondrial respiration or promote mitochondrial dysfunction by possibly affecting VDAC.

During apoptosis, however, Bcl-xL promotes the closing of VDAC to inhibit mitochondrial permeabilization (Shimizu et al. 1999), whereas Bax and Bak promote the open configuration of VDAC (Narita et al. 1998; Shimizu et al. 1999; Shimizu and Tsujimoto 2000). Although weak binding to ANT has been observed for Bcl-xL (Shimizu et al. 1999), the changes in mitochondrial permeability induced by Bcl-xL are most likely independent of ANT as the permeability of ANTdeficient mitochondria remains sensitive to $\mathrm{Bcl}-\mathrm{xL}$ expression (Shimizu et al. 2000). On the other hand, recombinant Bax is required for atractyloside-mediated opening of ANT in liposomes, suggesting that Bax may promote opening of the PT pore by affecting ANT (Marzo et al. 1998). Although Bax expression promotes ANTdependent cell death in yeast, ANT-deficient mitochondria are not resistant to Bax-induced permeabilization (Shimizu et al. 2000). Thus, the precise role of the MPT pore in apoptosis is still debated as the depletion of the VDAC isoforms did not influence MPT induction, caspase cleavage, or cell death. In addition, cells lacking both ANT1 and ANT2 remain responsive to most triggers of apoptosis. Therefore, the role of MPT as a possible mechanism to induce MOMP in apoptotic cell death is still a matter of debate. To date, the only bona fide component/modulator of MPT appears to be the CypD, because CypD-deficient cells are more resistant to MPT induction and cell death in comparison to wild-type cells.

The unexpected finding that the BH3-only protein, $\mathrm{Bad}$ (Bcl-2-associated death promoter), could regulate glucose-dependent mitochondrial respiration places the Bcl-2 family of proteins in a more direct role in regulating cell metabolism. Under nonapoptotic conditions, phosphorylated Bad is found in a mitochondrial protein complex comprising protein kinase A, WAVE-1 (a member of the Wiskott-Aldrich family and an A-kinase anchor 
protein), protein phosphatase 1, and glucokinase (hexokinase IV, a specific isoform found in liver cells and pancreatic $\beta$ cells; Danial et al. 2003). This complex is unable to form in Bad-deficient hepatocytes, which display decreased glucokinase activity and oxygen consumption, indicating that Bad is required for glucokinase complex assembly and function. Because glucokinase has a substantially higher $K_{\mathrm{m}}$ for glucose compared with hexokinases I-III (Postic et al. 2001), the physiological effect of a deficiency in glucokinase activity might be more apparent under hyperglycemic conditions. Indeed, Bad-deficient or knockin mice expressing unphosphorylatable Bad show decreased glucose clearance and insulin secretion in response to glucose tolerance (Danial et al. 2003, 2008). Altogether, these studies indicate that $\mathrm{Bad}$ functions at the interface between apoptosis and metabolism.

Bad is also found to influence the mitochondrial PT pore. Once dephosphorylated, Bad promotes mitochondrial permeability to $\mathrm{Ca}^{2+}$ and cell death through the PT pore by engaging VDAC and Bcl-xL (Roy et al. 2009). However, whether dephosphorylation of $\mathrm{Bad}$ is sufficient to disassemble the glucokinase complex to permit this apoptotic role in mitochondrial $\mathrm{Ca}^{2+}$ flux is still unclear. Other BH3-only proteins could also share a similar function in mitochondrial permeabilization, such as Bim, which was found to interact with VDAC to promote its opening and induce the loss of membrane potential during apoptosis (Sugiyama et al. 2002). In addition, the mitochondrial proapoptotic protein, Omi/HtrA2, may be involved to maintain mitochondrial integrity and limit the permeability transition, as mouse embryonic fibroblasts derived from mnd2 mutant mice, which express a spontaneous missense mutation in the protease domain of Omi/HtrA2, show sensitization to $\mathrm{Ca}^{2+}$-induced mitochondrial membrane permeabilization (Jones et al. 2003).

Several apoptotic factors can broadly influence cell metabolism by controlling the cellular redox state. For example, overexpression of Bcl-2 has been observed to protect against oxidative stress induced by $\mathrm{H}_{2} \mathrm{O}_{2}$ and menadione, a quinone compound that can be converted into superoxide radicals (Hockenbery et al. 1993). As antioxidants such as $\mathrm{N}$-acetylcysteine and glutathione peroxidase were also found to protect against apoptotic cell death, it was hypothesized that Bcl-2 could function as an antioxidant and limit ROS (reactive oxygen species) production. However, because the expression of Bcl-2 or $\mathrm{Bcl}-\mathrm{xL}$ was found to protect against cell death induced by hypoxia or oxygen starvation, which is predicted to decrease ROS production, the possibility that Bcl-2 might directly regulate cellular redox state is unfitting (Shimizu et al. 1995). Instead, Bcl-xL may have a broader role in regulating mitochondrial metabolism because ectopic expression of Bcl-xL enables yeast to switch from glycolytic to oxidative metabolism (Vander Heiden et al. 2002; Brace et al. 2005). Because oxidative metabolism is the major intracellular source for ROS production, it is still possible that $\mathrm{Bcl}-\mathrm{xL}$ influences the cellular redox state by affecting the cellular metabolic state in general. This suggests that Bcl-xL expression might influence mitochondrial metabolism by promoting aerobic metabolism and could have important implications in cancer development, which is discussed in further detail below.

\section{PART III. REGULATION OF APOPTOTIC SENSITIVITY BY METABOLISM}

As discussed above, the mitochondrion is intimately connected with apoptotic signaling because, first, the disruption of mitochondrial integrity is an important signal amplification mechanism during apoptosis, and second, select core apoptotic regulators directly participate in regulation of mitochondrial physiology. The coupling of apoptotic sensitivity and metabolism, however, is not limited to mitochondria only. Recent studies demonstrate that cellular metabolism has broad control over the activation of the apoptotic programs (Fig. 1). Such mechanisms include dynamic regulation of key apoptotic factors by specific posttranslational modifications that are remarkably sensitive to the cellular metabolic status.

\section{Metabolic Factors Directly Involved in Apoptotic Regulation}

As a direct consequence of the Warburg effect, most tumor cells use elevated amounts of glucose as a carbon source. Since enhanced glucose uptake can also protect normal cells such as neurons (Ravikumar et al. 2003), cardiomyocytes (Morissette et al. 2003) and hematopoietic cells (Rathmell et al. 2003) against apoptosis, the manner and the levels by which glucose is metabolized may have direct implications in regulating apoptotic sensitivity.

Reduction in mitochondrial respiration may provide a survival advantage by activating the phosphatidylinositol 3-kinase (PI3K)-Akt survival pathway (Pelicano et al. 2006), suggesting that increased glycolysis may possibly by itself promote Akt-mediated cell survival pathways. Moreover, apoptotic resistance to growth factor deprivation by Akt is dependent on glucose metabolism to mediate cell survival (Gottlob et al. 2001; Rathmell et al. 2003). Expression of constitutively active Akt promotes glucose-6-phosphate metabolism through glycolysis and the pentose phosphate pathway, which generates NADPH, and correlates with the suppression in Bax activation and cytochrome $c$ release. Exactly how metabolic changes elicited by Akt promote apoptotic inhibition is unclear. One possibility is that Akt coordinates glucose metabolism and caspase activation independently as Akt has been shown to mediate inhibitory phosphorylation of caspase-9 (Cardone et al. 1998). Akt may control caspase activation by regulating cell metabolism, which was suggested by a recent study showing that the levels of NADPH could directly influence caspase activation.

Kornbluth and colleagues report that generation of NADPH by the pentose phosphate pathway is critical for Xenopus oocyte survival under nutrient deprivation and that the target of this apoptosis inhibition is caspase- 2 


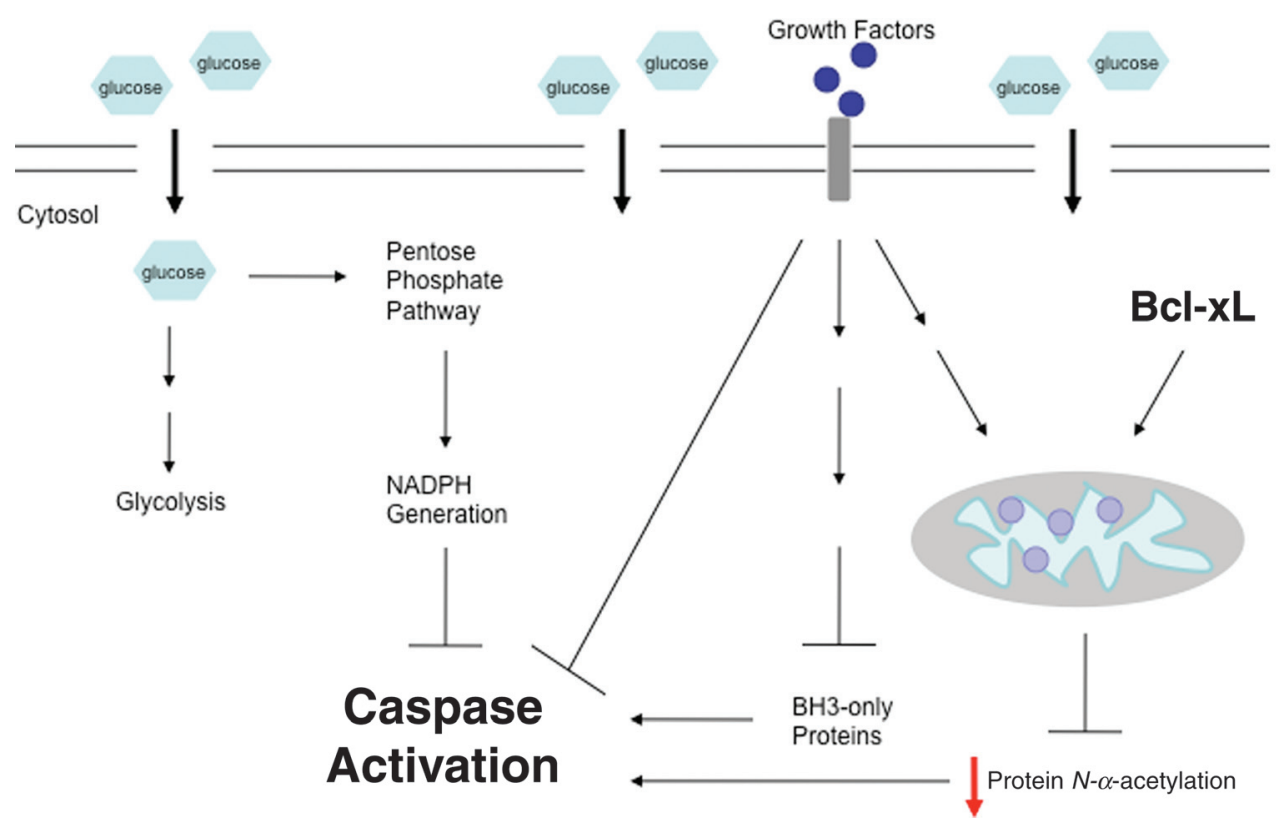

Figure 1. An emerging view of the metabolic pathways that regulate apoptosis. Growth factor signaling promotes cell survival by suppressing Bax-dependent mitochondrial permeabilization and cytochrome $c$ release (Rathmell et al. 2003). Alternatively, growth factor signaling suppresses caspase-9 via an Akt-dependent mechanism (Cardone et al. 1998). Two mechanisms have been described recently that directly implicate specific metabolites in regulating apoptotic sensitivity: NADPH and acetyl-CoA (Nutt et al. 2005, 2009; Yi et al. 2011). NADPH levels regulate caspase-2 activation via inhibitory phosphorylation by CAMKII, whereas acetyl-CoA levels regulate multiple apoptotic regulators via $N$ - $\alpha$-acetylation by amino-terminal acetyltransferase complexes.

(Nutt et al. 2005). In particular, NADPH, a major determinant of the redox potential of the cell, mediated inhibitory phosphorylation of caspase- 2 by calcium/ calmodulin-dependent kinase II (CaMKII), which interferes with the assembly of caspase-2-activating complex. Although oocytes rely entirely on internal glucose stores, whereas mammalian cells depend on the availability of glucose regulated by uptake, the increased levels of NADPH and up-regulation of the pentose phosphate pathway may also protect apoptosis of mammalian cells induced by growth factor deprivation and oxidative stress (Tian et al. 1999). Furthermore, cells deficient in glucose6-phosphate dehydrogenase, the key regulatory enzyme in the pentose phosphate shunt, are sensitized to ionizing radiation-induced cell death (Tuttle et al. 2000). More importantly, a similar mechanism regulating caspase- 2 in Xenopus oocytes was also found in murine oocytes, indicating that the metabolic regulation of caspase- 2 activation is well conserved (Nutt et al. 2009). Furthermore, the 14-3-3 protein, a chaperone that binds to specific phosphodomains, protects against dephosphorylation and caspase activation by binding to caspase- 2 when nutrients are plentiful (Nutt et al. 2009). Importantly metabolic control of the inhibitory phosphorylation on initiator caspases is conserved in Drosophila (Yang et al. 2010), frog (Nutt et al. 2005), and mammals (Nutt et al. 2009). Thus, increased production of NADPH may represent a major mechanism by which cellular metabolism is linked to the overall sensitivity of a cell to apoptosis.

\section{Integration of Mitochondrial Metabolism and Apoptotic Sensitivity}

Elevated glucose metabolism may directly regulate mitochondria apoptotic sensitivity in part by attenuating the degradation of antiapoptotic Bcl-2 family protein Mcl-1 (Zhao et al. 2007). Enforced expression of glucose transporter, Glut1, and hexokinase 1 (Glut1/HK1) stabilizes Mcl-1 via inhibitory phosphorylation of glycogen synthase kinase 3a and 3b (GSK-3a/b). Recently, phosphorylation of Mcl-1 by GSK-3a/b was shown to lead to mask a degron sequence that is normally recognized by an E3 ubiquitin ligase SCF (FBW7; a SKP1-cullin-1-F-box complex that contains FBW7 as the F-box protein; Inuzuka et al. 2011). Thus, phosphorylation and activation of GSK-3 by PKC in a glucosedependent manner may provide a connection from metabolism to Mcl-1 stabilization (Zhao et al. 2007). Since diacylglycerol is essential for mediating the activation of PKC, increased production of diacylglycerol as a result of glucose metabolism could provide a mechanism for metabolism to regulate the levels of Mcl-1.

As mentioned above, Bax and Bak can facilitate mitochondrial membrane permeability during apoptosis by interacting with VDAC. Several studies indicate that the activity of Bax and Bak under normal conditions might be regulated by VDAC2, a specific isoform of VDAC present only in mammals. Under nonapoptotic conditions, inactive Bak is found in a complex with VDAC-2, whereas under apoptotic conditions, Bak is 
released from VDAC2 to form homo-oligomeric complexes (Cheng et al. 2003; Chandra et al. 2005). The impact of VDAC2, however, may not be limited to only Bak-mediated mitochondrial damage as $\mathrm{VDAC}^{-/-}$ mouse embryonic fibroblasts (MEFs) also show a reduced sensitivity to tBid-mediated apoptosis and to Fas-mediated apoptosis (Roy et al. 2009). While VDAC2 does not bind to Bax in living cells (Cheng et al. 2003), it is found to coimmunoprecipitate with Bax in dying cells, suggesting that VDAC-2 might also regulate Baxdependent mitochondrial permeabilization during apoptosis (Yamagata et al. 2009).

\section{Metabolic Control of Protein Lysine Acetylation and Transcriptional Regulation of Apoptotic Sensitivity}

Acetylation is a posttranslational modification catalyzed by acetyltransferases that lead to the transfer of an acetyl group from acetyl-CoA to a protein substrate. Acetyl-CoA, an important product of glycolysis and fatty acid oxidation, is an essential cofactor for all protein acetylases. Condensing acetate and coenzyme A by acetylcoA synthetase leads to the production of acetyl-CoA. However, because most mammalian cells use glucose and not acetate as a major bioenergetic substrate under normal conditions, acetyl-coA synthetase may function in specific cell types and under specific physiological conditions. On the other hand, ATP-citrate lyase (ACL), which converts citrate, a TCA cycle intermediate, and coenzyme A into acetyl-coA and oxaloacetate, is a major producer of acetyl-CoA that is involved in shuttling mitochondrial acetyl-CoA into cytosol. Knockdown of ACL activity results in reduction of global histone acetylation and gene transcription; thus, ACL may play a major role in regulation of histone acetylation (Wellen et al. 2009).

Histone acetyltransferases mediate a type of acetylation involving covalent transfer of the acetyl group from acetyl-CoA to conserved lysine residues in the histone amino- and carboxy-terminal tails. In general, histone acetylation is coupled to transcriptional activation and associated with euchromatin as histone acetylations are required for the recruitment of ATP-dependent chromatin remodelers. Acetylations of lysine residues can be detected in many proteins. Since lysine acetylation may compete with other lysine-directed posttranslational modifications, such as ubiquitination and sumoylation, lysine acetylation of specific proteins may have functional significances in blocking their degradation and promoting their interactions with their partners. For example, acetylation of $\mathrm{p} 53$ may stabilize $\mathrm{p} 53$ by excluding ubiquitination on the same site, and recruit cofactors, which mediate p53 transcriptional activity. Nine acetylation sites have been identified in $\mathrm{p} 53$ that may be mediated by multiple acetyltransferases (Dai and $\mathrm{Gu} 2010$ ). One of the most interesting sites is the acetylation of K120, which occurs rapidly after DNA damage and is catalyzed by the MYST family acetyltransferases hMOF and
TIP60. Mutation of K120 to arginine, which occurs in human cancers, selectively blocks the transcription of proapoptotic target genes such as BAX and PUMA, whereas the expression of $\mathrm{p} 21$, a CDK inhibitor, is not affected. Thus, the acetylation of K120 in p53 might specifically affect the transcriptional targeting specificity of p53 (Sykes et al. 2006; Tang et al. 2006).

\section{Regulation of Apoptosis Sensitivity by Protein $N$ - $\boldsymbol{\alpha}$-Acetylation}

Protein $N-\alpha$-acetylation is a form of posttranslational modification in which an acetyl group is transferred from acetyl-CoA to the $\alpha$-amino group in the amino termini of nascent polypeptide chains. In yeast Saccharomyces cerevisiae, $N$ - $\alpha$-acetylation is catalyzed by three major amino-terminal acetyltransferase (NAT) complexes, NatA, NatB and NatC (Polevoda and Sherman 2003). Yeast mutants deficient in ard 1 are specifically defective in response to a mating factor response (Whiteway and Szostak 1985). In mammalian cells, protein $\mathrm{N}$ - $\alpha$-acetylation is mediated by five highly conserved $N$-acetyltransferase protein complexes (NatA, NatB, NatC, NatD, and NatE). The NatA complex consists of the catalytic subunit, Arrest Defective 1 (hNaa10p/ ARD1), and the auxiliary subunit, $N$-acetyltransferase 1 (NAT1/hNaa15p/NATH), whereas NatB consists of amino-terminal acetyltransferase 3 (hNaa20p/NAT3) and mitochondrial distribution and morphology 20 (hNaa25p/Mdm20). Although the Nat complexes are implicated in regulating cell cycle progression, cell proliferation, and tumorigenesis, the mechanisms that connect protein $N$ - $\alpha$-acetylation to cellular machineries are currently unknown (Polevoda and Sherman 2003; Ametzazurra et al. 2008; Starheim et al. 2008, 2009). Recent $\mathrm{N}$-acetylome studies reveal incomplete acetylation status of proteins (Arnesen et al. 2009; Goetze et al. 2009). Although it is commonly accepted that partial acetylation results from degenerate nature of protein amino-terminal sequences, the possibility that protein $N$ - $\alpha$-acetylation might be regulated has not be formally examined. Since acetyl-CoA is a key cofactor for protein $\mathrm{N}$ - $\alpha$-acetylation, the availability of acetyl-CoA might provide a mechanism for the integrated regulation of protein $N$ - $\alpha$-acetylation with metabolism.

ARD1 regulates DNA damage-mediated apoptosis in HeLa cells and is epistatic to the caspase inhibitor, DIAP1, in Drosophila Kc cells (Yi et al. 2007). Thus, protein $N$ - $\alpha$-acetylation could play a direct role in mediating caspase activation. Owing to the lack of a convenient method to reliably measure the levels of $N$ - $\alpha$-acetylation of proteins, the mechanism by which ARD1 regulates caspase activation was not revealed until very recently. Using a selective biotin labeling method with an engineered protein ligase, termed subtiligase (Abrahmsen et al. 1991), that detects nonacetylated amino termini of endogenous proteins and preferentially biotinylates amino-terminal amine groups consistent with the specificity of NatA or NatB, Yi et al. (2001) showed that caspase-2, 14-3-3b, Chk1, and Msh2 were 
biotinylated to a higher extent by subtiligase in NATH or ARD1 knockdown cells. This suggests that these proteins are indeed acetylated by the ARD1 complex. Moreover, a defect in caspase-2 acetylation was shown to impair the interaction of caspase-2 with RAIDD, an adaptor protein mediating its activation.

Because ARD1-mediated $N$ - $\alpha$-acetylation requires acetyl-CoA as an essential cofactor, Yi et al. (2001) propose that protein $N$ - $\alpha$-acetylation might be influenced by cellular metabolism. In a systematic approach using a combination of nuclear magnetic resonance (NMR) and mass spectrometry to identify metabolite changes associated with increased Bcl-xL expression, Yi et al. (2001) found that acetyl-CoA levels were significantly decreased in Bcl-xL expressing cells relative to control cells. In contrast, acetyl-CoA levels were substantially increased in Bcl-xL ${ }^{-/-}$MEFs compared with Bcl-xL $\mathrm{xL}^{+/+}$MEFs. The effect of Bcl-xL on metabolism is mediated through a Bax/Bak-independent mechanism as a similar reduction in acetyl-coA levels was observed in cells expressing the Bcl-xL F131V/D133A or G148E mutant, which are unable to bind to Bax or Bak but nevertheless retain $70 \%-80 \%$ antiapoptotic activity of wild-type Bcl-xL (Cheng et al. 1996). Consistently, MEFs that are double deficient for Bax and Bak show no difference in $N-\alpha-$ acetylation levels compared with that of wild-type cells. Moreover, the observed decrease in protein $N-\alpha-$ acetylation could be reversed by the addition of acetate or citrate, which stimulates cytoplasmic acetyl-CoA production and restores the apoptotic sensitivity of Bcl-xL overexpressing cells. Thus, regulation of protein $N-\alpha-$ acetylation as controlled by acetyl-CoA levels provides a new mechanism by which $\mathrm{Bcl}-\mathrm{xL}$ promotes cell survival that is independent of Bax/Bak. Since the defects of protein $N$ - $\alpha$-acetylation in Bcl-xL overexpressing cells affect multiple caspases and other apoptotic regulators, $N$ - $\alpha$-acetylation may regulate apoptotic sensitivity by controlling multiple apoptotic mediators (Fig. 2). Since mammalian apoptosis is controlled by a complex network of apoptotic signaling pathways, the ability of NAT complexes to simultaneously regulate multiple protein complexes by mediating protein $N$ - $\alpha$-acetylation is fully compatible with the operational need to integrate metabolism with apoptotic sensitivity.

\section{CONCLUDING REMARKS}

Our understanding of metabolic integration with apoptosis first came from the role of mitochondria, which play a central part in cellular energy production, in mediating apoptotic signaling. The permeabilization of the outer mitochondrial membrane during apoptosis, which leads to the release of key apoptotic regulators, such as cytochrome $c$, plays a key role in the signal transduction pathway of apoptosis from upstream proapoptotic Bcl-2 family members to downstream caspases. The role of key metabolic proteins, such as cytochrome $c$, in apoptotic signaling, suggests that dysregulation of mitochondrial metabolism might be important for the completion of apoptosis. The Bcl-2 family of proteins has also been

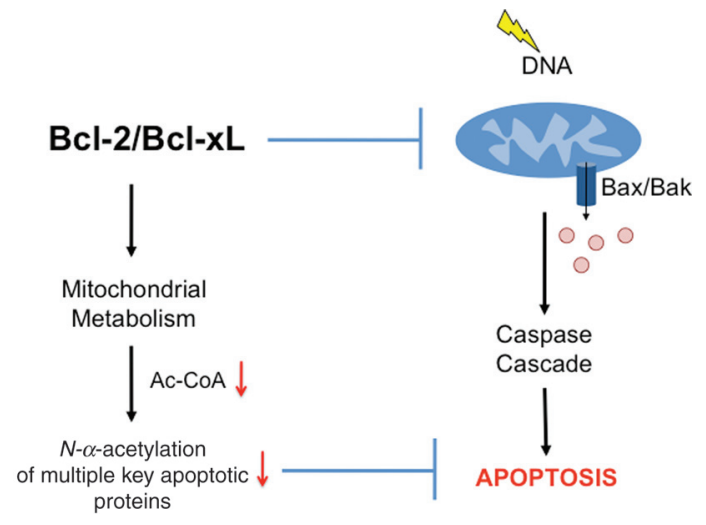

Figure 2. The dual role of Bcl-xL on cell survival by preventing $\mathrm{Bax} / \mathrm{Bak}$ oligomerization and protein $N$ - $\alpha$-acetylation. The mitochondrial protein Bcl-xL has two known functions: directly binding and inhibiting the proapoptotic proteins, Bax/Bak, to maintain mitochondrial integrity during apoptosis and to promote mitochondrial metabolism. A recent study demonstrates that the metabolic function of $\mathrm{Bcl}-\mathrm{xL}$ also contributes to cell survival. In addition to blocking Bax/Bak oligomerization during apoptosis, Bcl-xL also promotes cell survival by modulating acetyl-CoA levels, which leads to a reduction in the levels of protein $N$ - $\alpha$-acetylation (Yi et al. 2011). Protein $N$ - $\alpha$-acetylation, a type of posttranslational modification, is required for efficient induction of apoptotic cell death (Yi et al. 2007, 2011).

shown to interact with multiple members of the mitochondrial PT pore complexes, including VDAC, ANT, and $\mathrm{CyD}$, which either prevents or promotes mitochondrial damage.

The integration of metabolism and apoptosis, however, is not limited to mitochondria only. Recent evidence suggests that protein $N$ - $\alpha$-acetylation plays an important role in regulating apoptotic sensitivity. Protein acetylation, including both $N$ - $\alpha$-acetylation and lysine acetylation, is an important posttranslational modification that regulates cellular signaling. Since protein $N-\alpha$ - and lysine acetylations are an acetyl-coA-consuming process, metabolic regulation for the availability of acetyl-CoA may provide a critical control point to determine the levels and the targets of acetylation. The unexpected finding that Bcl-xL can regulate the levels of protein $N$ - $\alpha$-acetylation provides a prominent example of the oncogenic regulation of metabolism and apoptotic sensitivity. Overexpression of Bcl-xL exerts an important protective effect on maintaining the mitochondrial integrity in response to growth factor withdrawal or DNA damage. Bcl-xL has long been known to have dual functions in inhibiting Bax/Bakmediated mitochondrial damage during apoptosis and enhancing mitochondrial respiration; however, it was not known until recently that the mitochondrial function of Bcl-xL also contributes to apoptotic resistance (Vander Heiden et al. 1999, 2001, 2002; Gottlieb et al. 2000; Yi et al. 2011). The dual role of $\mathrm{Bcl}-\mathrm{xL}$ in preventing Bax/Bak oligomerization and protein $N$ - $\alpha$-acetylation might explain why $\mathrm{Bcl}-2 / \mathrm{Bcl}-\mathrm{xL}$ expression provides such strong inhibition of apoptosis. Since the ability of $\mathrm{Bcl}-\mathrm{xL}$ to regulate protein $N$ - $\alpha$-acetylation may have an impact on proteins other than apoptotic regulators, the oncogenic activity of $\mathrm{Bcl}-\mathrm{xL}$ may contribute to cancer 
development beyond increasing apoptosis resistance per se, which remains to be examined in future.

\section{ACKNOWLEDGMENTS}

This work was supported in part by an Innovator's Award from the U.S. Army Breast Cancer Research Program (grant DAMD17-02-1-0403), a grant from the National Institute of Aging (R37-012859), and a National Institutes of Health Director's Pioneer Award to J.Y.; a Kirchstein Nationa; Research Service Award from the National Institute of Neurological Disorders and Stroke (grant 1F31NS057872-01) to C.H.Y.; and a postdoctoral fellowship from the Swedish Society for Medical Research (SSMF) to H.V.N.

\section{REFERENCES}

Abrahmsen L, Tom J, Burnier J, Butcher KA, Kossiakoff A, Wells JA. 1991. Engineering subtilisin and its substrates for efficient ligation of peptide bonds in aqueous solution. Biochemistry 30: 4151-4159.

Acehan D, Jiang X, Morgan DG, Heuser JE, Wang X, Akey CW. 2002. Three-dimensional structure of the apoptosome: Implications for assembly, procaspase-9 binding, and activation. Mol Cell 9: 423-432.

Ametzazurra A, Larrea E, Civeira MP, Prieto J, Aldabe R. 2008. Implication of human $N$ - $\alpha$-acetyltransferase 5 in cellular proliferation and carcinogenesis. Oncogene 27: 7296-7306.

Arnesen T, Van Damme P, Polevoda B, Helsens K, Evjenth R, Colaert N, Varhaug JE, Vandekerckhove J, Lillehaug JR, Sherman F, et al. 2009. Proteomics analyses reveal the evolutionary conservation and divergence of N-terminal acetyltransferases from yeast and humans. Proc Natl Acad Sci 106: $8157-8162$.

Boise LH, Gonzalez-Garcia M, Postema CE, Ding L, Lindsten T, Turka LA, Mao X, Nunez G, Thompson CB. 1993. bcl-x, A bcl-2-related gene that functions as a dominant regulator of apoptotic cell death. Cell 74: 597-608.

Brace JL, Vanderweele DJ, Rudin CM. 2005. Svf1 inhibits reactive oxygen species generation and promotes survival under conditions of oxidative stress in Saccharomyces cerevisiae. Yeast 22: 641-652.

Brachmann CB, Jassim OW, Wachsmuth BD, Cagan RL. 2000. The Drosophila bcl-2 family member dBorg-1 functions in the apoptotic response to UV-irradiation. Curr Biol 10: $547-550$.

Cardone MH, Roy N, Stennicke HR, Salvesen GS, Franke TF, Stanbridge E, Frisch S, Reed JC. 1998. Regulation of cell death protease caspase-9 by phosphorylation. Science 282: 1318-1321.

Certo M, Del Gaizo Moore V, Nishino M, Wei G, Korsmeyer S, Armstrong SA, Letai A. 2006. Mitochondria primed by death signals determine cellular addiction to antiapoptotic BCL-2 family members. Cancer Cell 9: 351-365.

Chandra D, Choy G, Daniel PT, Tang DG. 2005. Bax-dependent regulation of Bak by voltage-dependent anion channel 2. $J$ Biol Chem 280: 19051-19061.

Chen L, Willis SN, Wei A, Smith BJ, Fletcher JI, Hinds MG, Colman PM, Day CL, Adams JM, Huang DC. 2005. Differential targeting of prosurvival Bcl-2 proteins by their $\mathrm{BH} 3$-only ligands allows complementary apoptotic function. Mol Cell 17: $393-403$.

Cheng EH, Levine B, Boise LH, Thompson CB, Hardwick JM. 1996. Bax-independent inhibition of apoptosis by Bcl-XL. Nature 379: 554-556.

Cheng EH, Wei MC, Weiler S, Flavell RA, Mak TW, Lindsten T, Korsmeyer SJ. 2001. BCL-2, BCL-X(L) sequester BH3 domain-only molecules preventing BAX-and BAK-mediated mitochondrial apoptosis. Mol Cell 8: 705-711.

Cheng EH, Sheiko TV, Fisher JK, Craigen WJ, Korsmeyer SJ. 2003. VDAC2 inhibits BAK activation and mitochondrial apoptosis. Science 301: 513-517.

Colussi PA, Quinn LM, Huang DC, Coombe M, Read SH, Richardson H, Kumar S. 2000. Debcl, a proapoptotic Bcl-2 homologue, is a component of the Drosophila melanogaster cell death machinery. J Cell Biol 148: 703-714.

Conus S, Rosse T, Borner C. 2000. Failure of Bcl-2 family members to interact with Apaf-1 in normal and apoptotic cells. Cell Death Differ 7: 947-954.

Dai C, Gu W. 2010. p53 Post-translational modification: Deregulated in tumorigenesis. Trends Mol Med 16: 528-536.

Danial NN, Gramm CF, Scorrano L, Zhang CY, Krauss S, Ranger AM, Datta SR, Greenberg ME, Licklider LJ, Lowell BB, et al. 2003. BAD and glucokinase reside in a mitochondrial complex that integrates glycolysis and apoptosis. Nature 424: $952-956$.

Danial NN, Walensky LD, Zhang CY, Choi CS, Fisher JK, Molina AJ, Datta SR, Pitter KL, Bird GH, Wikstrom JD, et al. 2008. Dual role of proapoptotic BAD in insulin secretion and $\beta$ cell survival. Nat Med 14: 144-153.

Degterev A, Boyce M, Yuan J. 2003. A decade of caspases. Oncogene 22: 8543-8567.

Dix MM, Simon GM, Cravatt BF. 2008. Global mapping of the topography and magnitude of proteolytic events in apoptosis. Cell 134: 679-691.

Duan H, Dixit VM. 1997. RAIDD is a new "death" adaptor molecule. Nature 385: 86-89.

Erlacher M, Labi V, Manzl C, Bock G, Tzankov A, Hacker G, Michalak E, Strasser A, Villunger A. 2006. Puma cooperates with Bim, the rate-limiting $\mathrm{BH} 3$-only protein in cell death during lymphocyte development, in apoptosis induction. $J$ Exp Med 203: 2939-2951.

Farrow SN, White JH, Martinou I, Raven T, Pun KT, Grinham CJ, Martinou JC, Brown R. 1995. Cloning of a bcl-2 homologue by interaction with adenovirus E1B 19K. Nature 374: 731-733.

Festjens N, Cornelis S, Lamkanfi M, Vandenabeele P. 2006. Caspase-containing complexes in the regulation of cell death and inflammation. Biol Chem 387: 1005-1016.

Galindo KA, Lu WJ, Park JH, Abrams JM. 2009. The Bax/Bak ortholog in Drosophila, Debcl, exerts limited control over programmed cell death. Development 136: 275-293.

Goetze S, Qeli E, Mosimann C, Staes A, Gerrits B, Roschitzki B, Mohanty S, Niederer EM, Laczko E, Timmerman E, et al. 2009. Identification and functional characterization of Nterminally acetylated proteins in Drosophila melanogaster. PLoS Biol 7: e1000236.

Gottlieb E, Vander Heiden MG, Thompson CB. 2000. Bcl-x(L) prevents the initial decrease in mitochondrial membrane potential and subsequent reactive oxygen species production during tumor necrosis factor $\alpha$-induced apoptosis. Mol Cell Biol 20: 5680-5689.

Gottlob K, Majewski N, Kennedy S, Kandel E, Robey RB, Hay N. 2001. Inhibition of early apoptotic events by Akt/PKB is dependent on the first committed step of glycolysis and mitochondrial hexokinase. Genes Dev 15: 1406-1418.

Green DR, Kroemer G. 2004. The pathophysiology of mitochondrial cell death. Science 305: 626-629.

Hao Z, Duncan GS, Chang CC, Elia A, Fang M, Wakeham A, Okada H, Calzascia T, Jang Y, You-Ten A, et al. 2005. Specific ablation of the apoptotic functions of cytochrome $\mathrm{C}$ reveals a differential requirement for cytochrome $\mathrm{C}$ and Apaf-1 in apoptosis. Cell 121: 579-591.

Hausmann G, O'Reilly LA, van Driel R, Beaumont JG, Strasser A, Adams JM, Huang DC. 2000. Pro-apoptotic apoptosis protease-activating factor 1 (Apaf-1) has a cytoplasmic localization distinct from Bcl-2 or Bcl-x(L). J Cell Biol 149: $623-634$.

Hockenbery DM, Oltvai ZN, Yin XM, Milliman CL, Korsmeyer SJ. 1993. Bcl-2 functions in an antioxidant pathway to prevent apoptosis. Cell 75: $241-251$. 
Igaki T, Kanuka H, Inohara N, Sawamoto K, Nunez G, Okano H, Miura M. 2000. Drob-1, a Drosophila member of the Bcl-2) CED-9 family that promotes cell death. Proc Natl Acad Sci 97: $662-667$.

Inuzuka H, Shaik S, Onoyama I, Gao D, Tseng A, Maser RS, Zhai B, Wan L, Gutierrez A, Lau AW, et al. 2011. $\mathrm{SCF}(\mathrm{FBW7})$ regulates cellular apoptosis by targeting MCL1 for ubiquitylation and destruction. Nature 471: 104-109.

Jones JM, Datta P, Srinivasula SM, Ji W, Gupta S, Zhang Z, Davies E, Hajnoczky G, Saunders TL, Van Keuren ML, et al. 2003. Loss of Omi mitochondrial protease activity causes the neuromuscular disorder of mnd2 mutant mice. Nature 425: $721-727$.

Jurgensmeier JM, Xie Z, Deveraux Q, Ellerby L, Bredesen D, Reed JC. 1998. Bax directly induces release of cytochrome c from isolated mitochondria. Proc Natl Acad Sci 95: 4997-5002.

Kamada S, Shimono A, Shinto Y, Tsujimura T, Takahashi T, Noda T, Kitamura Y, Kondoh H, Tsujimoto Y. 1995. bcl-2 Deficiency in mice leads to pleiotropic abnormalities: Accelerated lymphoid cell death in thymus and spleen, polycystic kidney, hair hypopigmentation, and distorted small intestine. Cancer Res 55: 354-359.

Kanuka H, Sawamoto K, Inohara N, Matsuno K, Okano H, Miura M. 1999. Control of the cell death pathway by Dapaf-1, a Drosophila Apaf-1/CED-4-related caspase activator. Mol Cell 4: 757-769.

Kluck RM, Bossy-Wetzel E, Green DR, Newmeyer DD. 1997. The release of cytochrome $\mathrm{c}$ from mitochondria: A primary site for Bcl-2 regulation of apoptosis. Science 275: $1132-1136$

Korsmeyer SJ, Shutter JR, Veis DJ, Merry DE, Oltvai ZN. 1993. Bcl-2/Bax: A rheostat that regulates an anti-oxidant pathway and cell death. Semin Cancer Biol 4: 327-332.

Kuwana T, Bouchier-Hayes L, Chipuk JE, Bonzon C, Sullivan BA, Green DR, Newmeyer DD. 2005. BH3 domains of $\mathrm{BH} 3$-only proteins differentially regulate Bax-mediated mitochondrial membrane permeabilization both directly and indirectly. Mol Cell 17: 525-535.

Letai A, Bassik MC, Walensky LD, Sorcinelli MD, Weiler S, Korsmeyer SJ. 2002. Distinct BH3 domains either sensitize or activate mitochondrial apoptosis, serving as prototype cancer therapeutics. Cancer Cell 2: 183-192.

Li P, Nijhawan D, Budihardjo I, Srinivasula SM, Ahmad M, Alnemri ES, Wang X. 1997. Cytochrome c and dATPdependent formation of Apaf-1/caspase-9 complex initiates an apoptotic protease cascade. Cell 91: 479-489.

Li K, Li Y, Shelton JM, Richardson JA, Spencer E, Chen ZJ, Wang X, Williams RS. 2000. Cytochrome c deficiency causes embryonic lethality and attenuates stress-induced apoptosis. Cell 101: 389-399.

Lindsten T, Ross AJ, King A, Zong WX, Rathmell JC, Shiels HA, Ulrich E, Waymire KG, Mahar P, Frauwirth K, et al. 2000. The combined functions of proapoptotic Bcl-2 family members bak and bax are essential for normal development of multiple tissues. Mol Cell 6: 1389-1399.

Liu X, Kim CN, Yang J, Jemmerson R, Wang X. 1996. Induction of apoptotic program in cell-free extracts: Requirement for dATP and cytochrome c. Cell 86: 147-157.

Liu X, Dai S, Zhu Y, Marrack P, Kappler JW. 2003. The structure of a Bcl-xL/Bim fragment complex: Implications for Bim function. Immunity 19: 341-352.

Lovell JF, Billen LP, Bindner S, Shamas-Din A, Fradin C, Leber B, Andrews DW. 2008. Membrane binding by tBid initiates an ordered series of events culminating in membrane permeabilization by Bax. Cell 135: 1074-1084.

Mahrus S, Trinidad JC, Barkan DT, Sali A, Burlingame AL, Wells JA. 2008. Global sequencing of proteolytic cleavage sites in apoptosis by specific labeling of protein $\mathrm{N}$ termini. Cell 134: 866-876.

Marsden VS, O'Connor L, O'Reilly LA, Silke J, Metcalf D, Ekert PG, Huang DC, Cecconi F, Kuida K, Tomaselli KJ, et al. 2002. Apoptosis initiated by Bcl-2-regulated caspase activation independently of the cytochrome c/Apaf-1/ caspase-9 apoptosome. Nature 419: 634-637.

Marzo I, Brenner C, Zamzami N, Jurgensmeier JM, Susin SA Vieira HL, Prevost MC, Xie Z, Matsuyama S, Reed JC, et al. 1998. Bax and adenine nucleotide translocator cooperate in the mitochondrial control of apoptosis. Science 281: 2027-2031.

McDonnell TJ, Deane N, Platt FM, Nunez G, Jaeger U, McKearn JP, Korsmeyer SJ. 1989. bcl-2-immunoglobulin transgenic mice demonstrate extended B cell survival and follicular lymphoproliferation. Cell 57: 79-88.

Minn AJ, Velez P, Schendel SL, Liang H, Muchmore SW, Fesik SW, Fill M, Thompson CB. 1997. Bcl-x(L) forms an ion channel in synthetic lipid membranes. Nature 385: $353-$ 357.

Miura M, Zhu H, Rotello R, Hartwieg EA, Yuan J. 1993. Induction of apoptosis in fibroblasts by IL-1 $\beta$-converting enzyme, a mammalian homolog of the $C$. elegans cell death gene ced-3. Cell 75: 653-660.

Moriishi K, Huang DC, Cory S, Adams JM. 1999. Bcl-2 family members do not inhibit apoptosis by binding the caspase activator Apaf-1. Proc Natl Acad Sci 96: 9683-9688.

Morissette MR, Howes AL, Zhang T, Heller Brown J. 2003. Upregulation of GLUT1 expression is necessary for hypertrophy and survival of neonatal rat cardiomyocytes. $J$ Mol Cell Cardiol 35: 1217-1227.

Motoyama N, Wang F, Roth KA, Sawa H, Nakayama K, Negishi I, Senju S, Zhang Q, Fujii S, Loh DY. 1995. Massive cell death of immature hematopoietic cells and neurons in Bcl-xdeficient mice. Science 267: 1506-1510.

Muchmore SW, Sattler M, Liang H, Meadows RP, Harlan JE, Yoon HS, Nettesheim D, Chang BS, Thompson CB, Wong SL, et al 1996. X-ray and NMR structure of human Bcl-xL, an inhibitor of programmed cell death. Nature 381: 335-341.

Nakayama K, Negishi I, Kuida K, Shinkai Y, Louie MC, Fields LE, Lucas PJ, Stewart V, Alt FW, Loh DY. 1993. Disappearance of the lymphoid system in Bcl-2 homozygous mutant chimeric mice. Science 261: 1584-1588.

Narita M, Shimizu S, Ito T, Chittenden T, Lutz RJ, Matsuda H, Tsujimoto Y. 1998. Bax interacts with the permeability transition pore to induce permeability transition and cytochrome $\mathrm{c}$ release in isolated mitochondria. Proc Natl Acad Sci 95: $14681-14686$.

Nechushtan A, Smith CL, Lamensdorf I, Yoon SH, Youle RJ. 2001. Bax and Bak coalesce into novel mitochondria-associated clusters during apoptosis. J Cell Biol 153: 12651276.

Nutt LK, Margolis SS, Jensen M, Herman CE, Dunphy WG, Rathmell JC, Kornbluth S. 2005. Metabolic regulation of oocyte cell death through the CaMKII-mediated phosphorylation of caspase-2. Cell 123: 89-103.

Nutt LK, Buchakjian MR, Gan E, Darbandi R, Yoon SY, Wu JQ, Miyamoto YJ, Gibbon JA, Andersen JL, Freel CD, et al. 2009. Metabolic control of oocyte apoptosis mediated by 14-3-3 $\zeta$-regulated dephosphorylation of caspase-2. Dev Cell 16: $856-866$.

Oh KJ, Barbuto S, Pitter K, Morash J, Walensky LD, Korsmeyer SJ. 2006. A membrane-targeted BID BCL-2 homology 3 peptide is sufficient for high potency activation of BAX in vitro. $J$ Biol Chem 281: 36999-37008.

Oltvai ZN, Milliman CL, Korsmeyer SJ. 1993. Bcl-2 heterodimerizes in vivo with a conserved homolog, Bax, that accelerates programmed cell death. Cell 74: 609-619.

Pelicano H, Xu RH, Du M, Feng L, Sasaki R, Carew JS, Hu Y, Ramdas L, Hu L, Keating MJ, et al. 2006. Mitochondrial respiration defects in cancer cells cause activation of Akt survival pathway through a redox-mediated mechanism. $J$ Cell Biol 175: 913-923.

Petros AM, Nettesheim DG, Wang Y, Olejniczak ET, Meadows RP, Mack J, Swift K, Matayoshi ED, Zhang H, Thompson CB, et al. 2000. Rationale for Bcl-xL/Bad peptide complex formation from structure, mutagenesis, and biophysical studies. Protein Sci 9: 2528-2534. 
Polevoda B, Sherman F. 2003. Composition and function of the eukaryotic N-terminal acetyltransferase subunits. Biochem Biophys Res Commun 308: 1-11.

Postic C, Shiota M, Magnuson MA. 2001. Cell-specific roles of glucokinase in glucose homeostasis. Recent Prog Horm Res 56: $195-217$.

Quinn LM, Dorstyn L, Mills K, Colussi PA, Chen P, Coombe M, Abrams J, Kumar S, Richardson H. 2000. An essential role for the caspase Dronc in developmentally programmed cell death in Drosophila. J Biol Chem 275: 40416-40424.

Rathmell JC, Fox CJ, Plas DR, Hammerman PS, Cinalli RM, Thompson CB. 2003. Akt-directed glucose metabolism can prevent Bax conformation change and promote growth factorindependent survival. Mol Cell Biol 23: 7315-7328.

Ravikumar B, Stewart A, Kita H, Kato K, Duden R, Rubinsztein DC. 2003. Raised intracellular glucose concentrations reduce aggregation and cell death caused by mutant huntingtin exon 1 by decreasing mTOR phosphorylation and inducing autophagy. Hum Mol Genet 12: 985-994.

Riedl SJ, Li W, Chao Y, Schwarzenbacher R, Shi Y. 2005. Structure of the apoptotic protease-activating factor 1 bound to ADP. Nature 434: 926-933.

Rodriguez A, Oliver H, Zou H, Chen P, Wang X, Abrams JM. 1999. Dark is a Drosophila homologue of Apaf-1/CED-4 and functions in an evolutionarily conserved death pathway. Nat Cell Biol 1: 272-279.

Rostovtseva TK, Antonsson B, Suzuki M, Youle RJ, Colombini M, Bezrukov SM. 2004. Bid, but not Bax, regulates VDAC channels. J Biol Chem 279: 13575-13583.

Roy SS, Madesh M, Davies E, Antonsson B, Danial N, Hajnoczky G. 2009a. Bad targets the permeability transition pore independent of Bax or Bak to switch between $\mathrm{Ca}^{2+}$ dependent cell survival and death. Mol Cell 33: 377-388.

Saito M, Korsmeyer SJ, Schlesinger PH. 2000. BAX-dependent transport of cytochrome c reconstituted in pure liposomes. Nat Cell Biol 2: 553-555.

Sentman CL, Shutter JR, Hockenbery D, Kanagawa O, Korsmeyer SJ. 1991. bcl-2 Inhibits multiple forms of apoptosis but not negative selection in thymocytes. Cell 67: $879-888$.

Shimizu S, Tsujimoto Y. 2000. Proapoptotic BH3-only Bcl-2 family members induce cytochrome c release, but not mitochondrial membrane potential loss, and do not directly modulate voltage-dependent anion channel activity. Proc Natl Acad Sci 97: 577-582.

Shimizu S, Eguchi Y, Kosaka H, Kamiike W, Matsuda H, Tsujimoto Y. 1995. Prevention of hypoxia-induced cell death by Bcl-2 and Bcl-xL. Nature 374: 811-813.

Shimizu S, Narita M, Tsujimoto Y. 1999. Bcl-2 family proteins regulate the release of apoptogenic cytochrome $\mathrm{c}$ by the mitochondrial channel VDAC. Nature 399: 483-487.

Shimizu S, Shinohara Y, Tsujimoto Y. 2000. Bax and Bcl-xL independently regulate apoptotic changes of yeast mitochondria that require VDAC but not adenine nucleotide translocator. Oncogene 19: 4309-4318.

Simon GM, Dix MM, Cravatt BF. 2009. Comparative assessment of large-scale proteomic studies of apoptotic proteolysis. ACS Chem Biol 4: 401-408.

Srinivasula SM, Hegde R, Saleh A, Datta P, Shiozaki E, Chai J, Lee RA, Robbins PD, Fernandes-Alnemri T, Shi Y, et al. 2001. A conserved XIAP-interaction motif in caspase-9 and Smac/DIABLO regulates caspase activity and apoptosis. Nature 410: 112-116.

Starheim KK, Arnesen T, Gromyko D, Ryningen A, Varhaug JE, Lillehaug JR. 2008. Identification of the human $\mathrm{N}(\alpha)$-acetyltransferase complex B (hNatB): A complex important for cellcycle progression. Biochem J 415: 325-331.

Starheim KK, Gromyko D, Velde R, Varhaug JE, Arnesen T. 2009. Composition and biological significance of the human $\mathrm{N} \alpha$-terminal acetyltransferases. BMC Proc 3 Suppl 6: pS3.

Strasser A, Harris AW, Bath ML, Cory S. 1990. Novel primitive lymphoid tumours induced in transgenic mice by cooperation between myc and bcl-2. Nature 348: 331-333.
Sugiyama T, Shimizu S, Matsuoka Y, Yoneda Y, Tsujimoto Y. 2002. Activation of mitochondrial voltage-dependent anion channel by apro-apoptotic $\mathrm{BH} 3$-only protein Bim. Oncogene 21: 4944-4956.

Sykes SM, Mellert HS, Holbert MA, Li K, Marmorstein R, Lane WS, McMahon SB. 2006. Acetylation of the p53 DNAbinding domain regulates apoptosis induction. Mol Cell 24: 841-851.

Tang Y, Luo J, Zhang W, Gu W. 2006. Tip60-dependent acetylation of p 53 modulates the decision between cell-cycle arrest and apoptosis. Mol Cell 24: 827-839.

Tian WN, Braunstein LD, Apse K, Pang J, Rose M, Tian X, Stanton RC. 1999. Importance of glucose-6-phosphate dehydrogenase activity in cell death. Am J Physiol 276: C1121-C1131.

Tinel A, Tschopp J. 2004. The PIDDosome, a protein complex implicated in activation of caspase-2 in response to genotoxic stress. Science 304: 843-846.

Tsujimoto Y. 1989. Stress-resistance conferred by high level of bcl-2 $\alpha$ protein in human B lymphoblastoid cell. Oncogene 4: $1331-1336$

Tsujimoto Y, Cossman J, Jaffe E, Croce CM. 1985a. Involvement of the bcl-2 gene in human follicular lymphoma. Science 228: $1440-1443$.

Tsujimoto Y, Gorham J, Cossman J, Jaffe E, Croce CM. 1985b. The $\mathrm{t}(14 ; 18)$ chromosome translocations involved in B-cell neoplasms result from mistakes in VDJ joining. Science 229: $1390-1393$.

Tsujimoto Y, Jaffe E, Cossman J, Gorham J, Nowell PC, Croce CM. 1985c. Clustering of breakpoints on chromosome 11 in human B-cell neoplasms with the $\mathrm{t}(11 ; 14)$ chromosome translocation. Nature 315: 340-343.

Tuttle S, Stamato T, Perez ML, Biaglow J. 2000. Glucose-6phosphate dehydrogenase and the oxidative pentose phosphate cycle protect cells against apoptosis induced by low doses of ionizing radiation. Radiat Res 153: 781-787.

Uren RT, Dewson G, Chen L, Coyne SC, Huang DC, Adams JM, Kluck RM. 2007. Mitochondrial permeabilization relies on $\mathrm{BH} 3$ ligands engaging multiple prosurvival $\mathrm{Bcl}-2$ relatives, not Bak. J Cell Biol 177: 277-287.

Van Damme P, Martens L, Van Damme J, Hugelier K, Staes A, Vandekerckhove J, Gevaert K. 2005. Caspase-specific and nonspecific in vivo protein processing during Fas-induced apoptosis. Nat Methods 2: 771-777.

Vander Heiden MG, Chandel NS, Williamson EK, Schumacker PT, Thompson CB. 1997. Bcl-xL regulates the membrane potential and volume homeostasis of mitochondria. Cell 91: $627-637$.

Vander Heiden MG, Chandel NS, Schumacker PT, Thompson CB. 1999. Bcl-xL prevents cell death following growth factor withdrawal by facilitating mitochondrial ATP/ADP exchange. Mol Cell 3: 159-167.

Vander Heiden MG, Li XX, Gottleib E, Hill RB, Thompson CB, Colombini M. 2001. Bcl-xL promotes the open configuration of the voltage-dependent anion channel and metabolite passage through the outer mitochondrial membrane. J Biol Chem 276: 19414-19419.

Vander Heiden MG, Choy JS, VanderWeele DJ, Brace JL, Harris MH, Bauer DE, Prange B, Kron SJ, Thompson CB, Rudin CM. 2002. Bcl-x(L) complements Saccharomyces cerevisiae genes that facilitate the switch from glycolytic to oxidative metabolism. J Biol Chem 277: 44870-44876.

Vaux DL, Weissman IL, Kim SK. 1992. Prevention of programmed cell death in Caenorhabditis elegans by human bcl-2. Science 258: 1955-1957.

Veis DJ, Sorenson CM, Shutter JR, Korsmeyer SJ. 1993. Bcl-2deficient mice demonstrate fulminant lymphoid apoptosis, polycystic kidneys, and hypopigmented hair. Cell 75: 229-240.

Walensky LD, Pitter K, Morash J, Oh KJ, Barbuto S, Fisher J, Smith E, Verdine GL, Korsmeyer SJ. 2006. A stapled BID BH3 helix directly binds and activates BAX. Mol Cell 24: 199-210. 
Warburg O. 1956. On respiratory impairment in cancer cells. Science 124: 269-270.

Wei MC, Zong WX, Cheng EH, Lindsten T, Panoutsakopoulou V, Ross AJ, Roth KA, MacGregor GR, Thompson CB, Korsmeyer SJ. 2001. Proapoptotic BAX and BAK: A requisite gateway to mitochondrial dysfunction and death. Science 292: $727-730$.

Wellen KE, Hatzivassiliou G, Sachdeva UM, Bui TV, Cross JR, Thompson CB. 2009. ATP-citrate lyase links cellular metabolism to histone acetylation. Science 324: 1076-1080.

Whiteway M, Szostak JW. 1985. The ARD1 gene of yeast functions in the switch between the mitotic cell cycle and alternative developmental pathways. Cell 43: 483-492.

Willis SN, Chen L, Dewson G, Wei A, Naik E, Fletcher JI, Adams JM, Huang DC. 2005. Proapoptotic Bak is sequestered by $\mathrm{Mcl}-1$ and Bcl-xL, but not Bcl-2, until displaced by BH3-only proteins. Genes Dev 19: 1294-1305.

Willis SN, Fletcher JI, Kaufmann T, van Delft MF, Chen L, Czabotar PE, Ierino H, Lee EF, Fairlie WD, Bouillet P, et al. 2007. Apoptosis initiated when BH3 ligands engage multiple Bcl-2 homologs, not Bax or Bak. Science 315: 856-859.

Wolter KG, Hsu YT, Smith CL, Nechushtan A, Xi XG, Youle RJ. 1997. Movement of Bax from the cytosol to mitochondria during apoptosis. J Cell Biol 139: 1281-1292.

Yamagata H, Shimizu S, Nishida Y, Watanabe Y, Craigen WJ, Tsujimoto Y. 2009. Requirement of voltage-dependent anion channel 2 for pro-apoptotic activity of Bax. Oncogene 28: $3563-3572$.

Yan N, Gu L, Kokel D, Chai J, Li W, Han A, Chen L, Xue D, Shi Y. 2004. Structural, biochemical, and functional analyses of CED-9 recognition by the proapoptotic proteins EGL-1 and CED-4. Mol Cell 15: 999-1006.

Yang E, Zha J, Jockel J, Boise LH, Thompson CB, Korsmeyer SJ. 1995. Bad, a heterodimeric partner for Bcl-XL and $\mathrm{Bcl}-2$, displaces Bax and promotes cell death. Cell 80: 285-291.

Yang J, Liu X, Bhalla K, Kim CN, Ibrado AM, Cai J, Peng TI, Jones DP, Wang X. 1997. Prevention of apoptosis by Bcl-2: Release of cytochrome c from mitochondria blocked. Science 275: $1129-1132$.

Yang X, Chang HY, Baltimore D. 1998. Essential role of CED-4 oligomerization in CED-3 activation and apoptosis. Science 281: $1355-1357$.
Yang CS, Thomenius MJ, Gan EC, Tang W, Freel CD, Merritt TJ, Nutt LK, Kornbluth S. 2010. Metabolic regulation of Drosophila apoptosis through inhibitory phosphorylation of Dronc. EMBO J 29: 3196-3207.

Yi CH, Sogah DK, Boyce M, Degterev A, Christofferson DE, Yuan J. 2007. A genome-wide RNAi screen reveals multiple regulators of caspase activation. J Cell Biol 179: 619-626.

Yi CH, Pan H, Seebacher J, Jang IH, Hyberts SG, Heffron GJ, Vander Heiden MG, Yang R, Li F, Locasale JW, et al. 2011. Metabolic regulation of protein $N$ - $\alpha$-acetylation by Bcl-xL promotes cell survival. Cell 146: 607-620.

Yu T, Wang X, Purring-Koch C, Wei Y, McLendon GL. 2001. A mutational epitope for cytochrome $\mathrm{C}$ binding to the apoptosis protease activation factor-1. J Biol Chem 276: $13034-13038$.

Yuan J. 2006. Divergence from a dedicated cellular suicide mechanism: Exploring the evolution of cell death. Mol Cell 23: $1-12$.

Yuan J, Shaham S, Ledoux S, Ellis HM, Horvitz HR. 1993. The C. elegans cell death gene ced-3 encodes a protein similar to mammalian interleukin-1 $\beta$-converting enzyme. Cell 75: $641-652$

Zhang H, Huang Q, Ke N, Matsuyama S, Hammock B, Godzik A, Reed JC. 2000. Drosophila pro-apoptotic Bcl-2/Bax homologue reveals evolutionary conservation of cell death mechanisms. J Biol Chem 275: 27303-27306.

Zhao Y, Altman BJ, Coloff JL, Herman CE, Jacobs SR, Wieman HL, Wofford JA, Dimascio LN, Ilkayeva O, Kelekar A, et al. 2007. Glycogen synthase kinase $3 \alpha$ and $3 \beta$ mediate a glucose-sensitive antiapoptotic signaling pathway to stabilize Mcl-1. Mol Cell Biol 27: 4328-4339.

Zhou L, Song Z, Tittel J, Steller H. 1999. HAC-1, a Drosophila homolog of APAF-1 and CED-4 functions in developmental and radiation-induced apoptosis. Mol Cell 4: 745-755.

Zong WX, Lindsten T, Ross AJ, MacGregor GR, Thompson CB. 2001. BH3-only proteins that bind pro-survival Bcl-2 family members fail to induce apoptosis in the absence of Bax and Bak. Genes Dev 15: 1481-1486.

Zoratti M, Szabo I. 1995. The mitochondrial permeability transition. Biochim Biophys Acta 1241: 139-176.

Zou H, Henzel WJ, Liu X, Lutschg A, Wang X. 1997. Apaf-1, a human protein homologous to C. elegans CED-4, participates in cytochrome c-dependent activation of caspase-3. Cell 90: $405-413$. 


\section{$\$_{\mathrm{CSH}}^{\infty}$ Cold Spring Harbor Symposia SYMPOSIA on Quantitative Biology}

\section{Integration of Apoptosis and Metabolism}

C.H. Yi, H. Vakifahmetoglu-Norberg and J. Yuan

Cold Spring Harb Symp Quant Biol 2011 76: 375-387 originally published online November 16, 2011

Access the most recent version at doi:10.1101/sqb.2011.76.010777 $\begin{array}{ll}\text { References } & \begin{array}{l}\text { This article cites } 130 \text { articles, } 47 \text { of which can be accessed free at: } \\ \text { http://symposium.cshlp.org/content/76/375.full.html\#ref-list-1 }\end{array}\end{array}$

\section{License}

Email Alerting

Service

Receive free email alerts when new articles cite this article - sign up in the box at the top right corner of the article or click here. 